\title{
Efficiency Analysis of Listed Agricultural Company Based on DEA
}

\author{
Jiandong Zhang and Jian Zhang* \\ Dalian Polytechnic University, Dalian City, Liaoning Province, China \\ ${ }^{*}$ Corresponding author
}

\begin{abstract}
Based on the data of 10 listed agricultural companies from 2011 to 2015, this paper analyzes the technology and scale efficiency of 10 listed agricultural companies by Data Envelopment Analysis (DEA). The results show that: the listed companies that have the best technical efficiency and economies of scale at the same time have fewer listed agricultural products, but they can be further improved. Finally, some suggestions are put forward.
\end{abstract}

\section{Keywords-DEA; technical efficiency; scale efficiency}

\section{INTRODUCTION}

As the primary industry in our country, agriculture has always been the focus of our country's work. According to statistics, as of 2016, China's agricultural output value has been steadily rising, but China's agricultural products processing industry is at a low level, productivity of agricultural products is low, the degree of commercialization is low. In the process of social development, the special efficiency of listed agricultural companies to achieve the technical, pure technical and scale efficiency is less than optimal. Under the current social market economy, to enhance the competitiveness of listed agricultural products and optimize the industrial structure, it is necessary to change from the most basic input-output relationship, improve business productivity and efficiency. Therefore, this paper uses data envelopment model (DEA) to conduct empirical analysis of Liaoning listed agricultural products companies, which is of great practical significance to improve the competitiveness of agricultural products processing enterprises and enhance the efficiency of listed companies.

\section{LitERATURE REVIEW}

In our country, agricultural listed companies play an important role in agriculture. In recent years, Chinese scholars have analyzed the agricultural listed companies from different angles, for example

Scholar Chen Hao (2013) based on technological innovation of agricultural listed companies financial comprehensive evaluation index system, and then used the principal component analysis to calculate the selected 12 agricultural listed companies financial composite score to evaluate their financial status[1].Chen Wei, Zhang Lei and so on(2014) applying the three-stage DEA model, the effectiveness of informatization construction in colleges and universities was evaluated on the basis of eliminating the influence of environment and random factors[2]. Xiong Chan, YiYuan-Yuan and so on(2014) analyze the situation of redundant and underemployed high-tech start-ups that are non-DEA effective in all regions[3].LI Xiao-mei, Bai Xue-fei(2016)based on the panel data of 16 state-owned logistics enterprises listed in A shares from 2006 to 2015, this paper empirically tests purely technical efficiency, scale efficiency and overall efficiency of state-owned logistics enterprises from a micro perspective[4].

To sum up, Chinese scholars have conducted many research on listed agricultural products companies, using a variety of methods for analysis. This paper uses data envelopment analysis is purely technical and has nothing to do with the market price, just need to distinguish between output and output, the number of cases is not high This article mainly selects the data of 10 listed agricultural products and adopts the method of Data envelope analysis (DEA), Listed companies in the agricultural products in terms of technology and efficiency made recommendations to other listed companies of agricultural products also have reference.

\section{RESEARCH DESIGN}

\section{A. Case Selection and Data Source}

This article mainly elects 10 listed agricultural products as the research object, including Bei Da Huang Co., Ltd.(A1), Denghai Seed Co., Ltd.(A2), Easysight Asysight Supply Chain Management Co., Ltd.(A3), New Hope Liuhe Co.,Ltd. (A4), Gansu Ronghua Industry Group Co.,Ltd.(A5).Shandong Ruyi Woolen Garment Group Co., Ltd.(A6), New Wellful Co.,Ltd.(A7), Wellhope Agri-Tech Joint Stock Co., Ltd.(A8), Yi Qiao Sea Cucumber Co.,Ltd.(A9.), Tianbao Green Foods Co., Ltd.(A10). Data sources for Sina Finance and other securities website on the case of the company announced 2011 2015 annual report.

\section{B. Case Index Introduction}

Input and output indexes established by DEA analysis method include total assets $(\mathrm{X})$, operating costs $(\mathrm{Y})$, operating income $(\mathrm{Z})$, net profit $(\mathrm{H})$ and earnings per share $(\mathrm{F})$.

\section{DAta EnVElopment AnAlysis(DEA)}

This paper uses BCC model with variable returns to scale.

Processing of DEA data

The case studies in this paper must be selected from publicly listed agricultural product listed companies with guaranteed data quality, a total of 10 listed companies in agricultural products to conduct research and analysis, the data source for agricultural products listed companies open annual 
reports. According to DEA analysis for data selection restrictions, the data as much as possible, so in the analysis of the data, the negative value of the case company is normalized to 1. According to DEA analysis of data cases require decision-making unit number analysis(Double the sum of input and output indicators must be less than the number of cases), the research data in this paper meets the DEA case requirements, the selected indicators are the average of the original case indicators from 2011 to 2015 as shown in Table 1:

TABLE I. THE AVERAGE OUTPUT OF THE COMPANY AND INPUT INDICATORS THE ORIGINAL DATA IN $2011 \sim 2015$

\begin{tabular}{|c|c|c|c|c|c|}
\hline $\begin{array}{c}\text { Listed } \\
\text { company }\end{array}$ & $\begin{array}{c}\text { operating } \\
\text { income }\end{array}$ & net profit & $\begin{array}{c}\text { earnings } \\
\text { per share }\end{array}$ & total assets & $\begin{array}{c}\text { operating } \\
\text { costs }\end{array}$ \\
\hline $\mathrm{A}_{1}$ & 9006344000 & 187803000 & 0.15 & 12602992000 & $\begin{array}{c}892114400 \\
0\end{array}$ \\
\hline $\mathrm{A}_{2}$ & 1368006000 & 494393600 & 0.78 & 3379654000 & 890584800 \\
\hline $\mathrm{A}_{3}$ & 1366361600 & 96060840 & 0.17 & 2516554800 & $\begin{array}{c}123647120 \\
0\end{array}$ \\
\hline $\mathrm{A}_{4}$ & 69161100000 & 2720580000 & 1.15 & 28908340000 & $\begin{array}{c}682584400 \\
00\end{array}$ \\
\hline $\mathrm{A}_{5}$ & 225010740 & 2460400 & 0.003 & 995924800 & 173949940 \\
\hline $\mathrm{A}_{6}$ & 641356800 & 6192272 & 0.04 & 1832196000 & 637328800 \\
\hline $\mathrm{A}_{7}$ & 1151575400 & 7657540 & 0.09 & 1171000800 & $\begin{array}{c}117396780 \\
0\end{array}$ \\
\hline $\mathrm{A}_{8}$ & 8551298000 & 263583000 & 0.46 & 3379040000 & $\begin{array}{c}826557800 \\
0\end{array}$ \\
\hline $\mathrm{A}_{9}$ & 446501400 & 180225000 & 0.54 & 2398276000 & $\begin{array}{c}268779000 \\
0\end{array}$ \\
\hline
\end{tabular}

UNIT: YUAN

\section{Analysis of TECHNiCAL EfFiciency, Pure TECHNICAL EFFICIENCY AND SCALE EFFICIENCY}

According to the variable-scale returns model, using deap2.1 software data to solve the problem, the paper obtains the comparison of technical efficiency and scale efficiency of listed companies in different agricultural products from 2011 to 2015, and reflects the efficiency difference of agricultural listed companies from the efficiency point of view (Table 2).
TABLE II. CALCULATION RESULTS OF DEA MODEL

\begin{tabular}{|c|c|c|c|c|}
\hline \multirow{2}{*}{$\begin{array}{l}\text { company } \\
\text { name } \\
\text { years } \\
\text { Efficiency } \\
\text { value }\end{array}$} & \multicolumn{4}{|c|}{ 2011 2015 } \\
\hline & $\rho_{0}^{*}$ & $\theta_{0}^{*}$ & $\mathrm{~S}_{0}^{*}$ & $\begin{array}{l}\text { Diminishing } \\
\text { returns to } \\
\text { scale }\end{array}$ \\
\hline A1 & 0.853 & 0.951 & 0.897 & drs \\
\hline A2 & 1 & 1 & 1 & - \\
\hline A3 & 0.866 & 0.894 & 0.969 & irs \\
\hline A4 & 1 & 1 & 1 & - \\
\hline A5 & 0.817 & 1 & 0.817 & irs \\
\hline A6 & 0.719 & 0.802 & 0.897 & irs \\
\hline A7 & 0.874 & 1 & 0.874 & irs \\
\hline A8 & 1 & 1 & 1 & - \\
\hline A9 & 1 & 1 & 1 & - \\
\hline A10 & 0.932 & 0.971 & 0.960 & irs \\
\hline
\end{tabular}

Note: $\rho^{*}$ represents technical efficiency value, $\theta^{*}$ represents pure technical efficiency value, $S^{*}$ represents scale efficiency. Drs represents diminishing returns of scale, Ins represents the increasing of scale.

\section{A. Technical Efficiency Analysis}

According to the technical efficiency $\rho^{*}$ shown in Table 2, we can conclude that the technical efficiency of 10 listed agricultural companies from 2011 to 2015 is only 1, about $40 \%$ of the total cases, this shows that the four companies in the 2011 2015 development momentum is good, and have reached the effective value of 1 , it is possible that this is due to the support of the formulation of policies by national authorities in recent years and the improvement of their own technologies; Other companies still have inefficient DEA, accounting for $60 \%$ of the total, This shows that the above companies have experienced a certain degree of overall decline. they need to adjust their input structure appropriately and strengthen their management of resources input.

\section{B. Pure Technical Efficiency Analysis}

As can be seen from the purely technical efficiency $\theta^{*}$ of Table 2, there are six cases of listed agricultural product companies achieved purely technical efficiency during 2011-2015, accounting for $60 \%$ of the total cases, These figures indicate that the growth momentum of these companies is good while the pure technical efficiency of other companies from 2011 to 2015 are $0.951,0.849,0.802$ and 0.971 respectively, accounting for $40 \%$ of the total. This shows that purely technical efficiency is not effective and DEA has not reached the effective level. 


\section{Scale Efficiency Analysis}

According to the data from table 2, the pure scale efficiency values $S^{*}$ are shown,In $2011 \sim 2015$, there are four cases of listed agricultural product companies achieving economies of scale. accounting for $40 \%$ of the total cases. While the other companies scale efficiency were 0.897, 0.969,
$0.817,0.897,0.874$ and 0.960 , accounting for $60 \%$ of the total cases.Indicating that the overall difference is not large, but it did not achieve economies of scale, DEA invalid. Agricultural listed companies in the smaller size of the capital mainly for the smaller size of the stock, asset size is small and the market size is small and so on.

TABLE III. ANNUAL DATA CALCULATION RESULTS OF DEA MODEL

\begin{tabular}{|c|c|c|c|c|c|c|c|c|c|c|c|c|c|c|c|}
\hline & $\begin{array}{c}2011 \\
\rho^{*}\end{array}$ & $\begin{array}{c}\mathbf{2 0 1 2} \\
\rho^{*}\end{array}$ & $\begin{array}{c}\mathbf{2 0 1 3} \\
\rho^{*}\end{array}$ & $\begin{array}{c}\mathbf{2 0 1 4} \\
\rho^{*}\end{array}$ & $\begin{array}{c}\mathbf{2 0 1 5} \\
\rho^{*}\end{array}$ & $\begin{array}{c}\mathbf{2 0 1 1} \\
\theta^{*}\end{array}$ & $\begin{array}{c}\mathbf{2 0 1 2} \\
\theta^{*}\end{array}$ & $\begin{array}{c}\mathbf{2 0 1 3} \\
\theta^{*}\end{array}$ & $\begin{array}{c}\mathbf{2 0 1 4} \\
\theta^{*}\end{array}$ & $\begin{array}{c}2015 \\
\theta^{*}\end{array}$ & $\begin{array}{c}\mathbf{2 0 1 1} \\
S^{*}\end{array}$ & $\begin{array}{c}2012 \\
S^{*}\end{array}$ & $\begin{array}{c}2013 \\
S^{*}\end{array}$ & $\begin{array}{c}2014 \\
S^{*}\end{array}$ & $\begin{array}{c}2015 \\
S^{*}\end{array}$ \\
\hline $\mathrm{A}_{1}$ & 0.83 & 0.84 & 0.80 & 0.86 & 0.97 & 0.97 & 0.95 & 0.90 & 1 & 1 & 0.86 & 0.88 & 0.89 & 0.86 & 0.97 \\
\hline $\mathrm{A}_{2}$ & 1 & 1 & 1 & 1 & 1 & 1 & 1 & 1 & 1 & 1 & 1 & 1 & 1 & 1 & 1 \\
\hline $\mathrm{A}_{3}$ & 0.98 & 1 & 1 & 1 & 0.86 & 1 & 1 & 1 & 1 & 0.94 & 0.98 & 1 & 1 & 1 & 0.92 \\
\hline $\mathrm{A}_{4}$ & 1 & 1 & 1 & 0.97 & 0.96 & 1 & 1 & 1 & 1 & 1 & 1 & 1 & 1 & 0.97 & 0.96 \\
\hline $\mathrm{A}_{5}$ & 0.97 & 0.81 & 0.80 & 0.71 & 0.62 & 1 & 1 & 1 & 1 & 1 & 0.97 & 0.81 & 0.80 & 0.71 & 0.62 \\
\hline $\mathrm{A}_{6}$ & 0.67 & 0.73 & 0.67 & 0.70 & 0.75 & 0.67 & 0.75 & 0.67 & 0.70 & 0.89 & 0.99 & 0.98 & 1 & 1 & 0.84 \\
\hline $\mathrm{A}_{7}$ & 1 & 0.89 & 0.86 & 0.84 & 0.87 & 1 & 0.95 & 0.86 & 0.84 & 1 & 1 & 0.93 & 1 & 1 & 0.87 \\
\hline $\mathrm{A}_{8}$ & 1 & 1 & 1 & 1 & 1 & 1 & 1 & 1 & 1 & 1 & 1 & 1 & 1 & 1 & 1 \\
\hline $\mathrm{A}_{9}$ & 1 & 1 & 1 & 1 & 1 & 1 & 1 & 1 & 1 & 1 & 1 & 1 & 1 & 1 & 1 \\
\hline $\mathrm{A}_{10}$ & 0.89 & 0.86 & 0.77 & 0.79 & 0.82 & 1 & 0.87 & 0.78 & 0.81 & 0.83 & 0.89 & 0.98 & 1 & 0.98 & 0.99 \\
\hline
\end{tabular}

According to the numerical results shown in Table 3, there are three cases of listed agricultural products companies achieving economies of scale accounting for about $30 \%$ of the total cases in 2011-2015. However, other companies did not reach the optimal scale, accounting for $70 \%$ of the total efficiency, at the same time, the most optimal technical efficiency, optimal pure technical efficiency and optimal scale efficiency are the most, about 20\% of the total years in 2014 .

\section{SUGGESTIONS}

In terms of technical capabilities, first, making core innovation strategy, the primary development of technology is innovation, we should make the core innovation strategy, focus on the overall trend of economic development. Second, establishing and perfecting a scientific human resources management system, we must pay attention to the cultivation of innovative talents, we should give preferential policies to those who have innovation ability, and attract high-quality talents with higher treatment.

In terms of scale conditions, we should pay attention to the scale of operation. First, create a good external environment, nowadays, the demand for agricultural products has not changed much in the market, and the recognition of some agricultural products is not too high, we should step up product promotion. At the same time, we use the good policy support from the national government to develop our own product management[5]. Second, at the same time we can develop a strict system of rewards and punishments, award rewards and punishments, the punishment of employees severely punished, let other employees take warning, at the same time, reward some employees should be rewarded, in order to enhance the enthusiasm of staff.

\section{REFERENCES}

[1] Hao Chen .Analysis of Financial Comprehensive Evaluation of Agricultural Listed Companies Based on Technological Innovation [J]. China Township Enterprises Accounting, 2013, (01): 79-81.

[2] Weiwei Chen, Lei Zhang, Ma randomised,Qiusui Liu. Some Research on The ThreeStage DEA Model [J]. Systems Engineering, 2014, (09): 144-149.

[3] Chan Xiong, YiYuan-Yuan, Xiao-Bin He, Ren-Qiao Xiao.Study on Operational Efficiency of Chinese High-tech Start-up Enterprises Based on DEA Method [J] .Management Science, 2014,27 (02): 26-37.

[4] Xiao-mei LI, Xue-fei Bai.Analysis of Performance of State-owned Logistics Enterprises Based on Super Efficiency CCR-DEA - Based on Sample Data of 16 Listed Logistics Enterprises [J]. China's Circulation Economy, 2016,30 (04): 26-32.

[5] Weiguang Wang, Hongwei Gao, Xuefei Bai , An Empirical Study on Localization of Technological Innovation System of Large Enterprises in China - An Analysis Based on Regional Level, China Industrial Economics | Chin Ind Econ, 2011, 12: 67-77. 